\title{
HUMAN RIGHTS AND EQUALITY IN NORTHERN IRELAND
}

\author{
Colin Harvey, Human Rights Centre, School of Law, Queen's \\ University Belfast
}

\section{Introduction}

The aim of this article is to outline the position in Northern Ireland on human rights and equality following the Belfast Agreement 1998. ${ }^{1}$ The article is based on the premise that the Agreement represents a "constitutional moment" in the history of Northern Ireland which has left a significant political and legal legacy and within which concepts of both human rights and equality are intended to play a key role. ${ }^{2}$ The principles underpinning the Agreement are at the core of the "political constitution" of Northern Ireland, with the Northern Ireland Act 1998 as a "new constitution", and all secured by bilateral agreements between the British and Irish governments. ${ }^{3}$

The Agreement provided the impetus for a more intense focus on human rights protection and promotion. It brought human rights from the "margins to the mainstream". ${ }^{4}$ The intention here is to explore selected developments in Northern Ireland to illustrate the nature of the governing framework. The article is in two stages: first, the framework for the promotion and protection of human rights in Northern Ireland is outlined; and second, some consideration is given to current debates on equality. The suggestion is that

1 Agreement Reached in the Multi-Party Negotiations (Cm 3883, 1998). The Belfast Agreement comprises both the Multi-Party Agreement and the British-Irish Agreement.

2 For analysis of the Agreement see: Brendan O'Leary "The Nature of the Agreement" (1999) 22 Fordham International Law Journal 1628; Brendan O'Leary "The Nature of the British-Irish Agreement" (1999) 233 New Left Review 66; Brendan O'Leary "The Character of the 1998 Agreement: Results and Prospects" in Wilford (ed.) Aspects of the Belfast Agreement (2001) 49; John McGarry and Brendan O'Leary The Northern Ireland Conflict: Consociational Engagements (2004); Austen Morgan The Belfast Agreement: a practical legal analysis (2000); Kieran McEvoy and John Morison "Beyond the "Constitutional Moment': Law, Transition and Peacemaking in Northern Ireland" (2003) 26 Fordham International Law Journal 961; Gordon Anthony "Public Law Litigation and the Belfast Agreement" (2002) 8 European Public Law 401. For the wider context see Brendan O'Leary and John McGarry The Politics of Antagonism: Understanding Northern Ireland ( $2^{\text {nd }}$ ed., 1996); John McGarry 'Democracy' in Northern Ireland: experiments in self-rule from the Protestant Ascendancy to the Good Friday Agreement" (2002) 8 Nations and Nationalism 451.

3 Robinson v Secretary of State for Northern Ireland [2002] UKHL 32.

4 Paul Mageean and Martin O'Brien "From the Margins to the Mainstream: Human Rights and the Good Friday Agreement" (1999) 22 Fordham International Law Journal 1499; Brice Dickson "Protection of Human Rights - Lessons from Northern Ireland" [2000] European Human Rights Law Review 213; Colin Harvey and Stephen Livingstone "Human Rights and the Northern Ireland Peace Process" [1999] European Human Rights Law Review 162. 
rights and equality should play a central part in the governing process. Although practice may diverge substantially from the agreed principles, these commitments retain considerable significance.

\section{Promoting and Protecting Human Rights}

\section{Human Rights, the Belfast Agreement and the Northern Ireland Act 1998}

First the Belfast Agreement 1998 and its provisions on human rights protection and promotion must be examined. The Agreement includes several references to human rights. As one would expect, its language is not fully replicated in the Northern Ireland Act 1998, but the legislation generally reflects the human rights commitments contained in the Agreement. The express purpose of the 1998 Act is to implement the Agreement. ${ }^{5}$ The Northern Ireland Act 1998 has been described as a new constitution for Northern Ireland and it has been interpreted with this in mind. ${ }^{6}$

The Agreement contains a section entitled Rights, Safeguards and Equality of Opportunity but the language of rights is to be found in other sections. The Declaration of Support commits the participants to the "protection and vindication of the human rights of all". It also contains recognition of continuing disagreement:

"We acknowledge the substantial differences between our continuing, and equally legitimate, political aspirations. However, we will endeavour to strive in every practical way towards reconciliation and rapprochement within the framework of democratic and agreed arrangements."

The right of self-determination is addressed in a formulation which is linked to concurrent consent in both parts of Ireland. ${ }^{9}$ The status of Northern Ireland ultimately rests on the consent of a majority of its population and the current preference appears to be for continuing membership of the UK. The principle is now reflected in section 1 of the Northern Ireland Act 1998 as well as in the Irish constitution. ${ }^{10}$ The notion of "double protection" captures the role of rights within this constitutional picture. ${ }^{11}$ The theory is that whatever choice is made by the people of Northern Ireland the power of the government with jurisdiction there:

"shall be exercised with rigorous impartiality on behalf of all the people in the diversity of their identities and traditions and shall be founded on the principles of full respect for, and equality of, civil, political, social and cultural rights, of

5 The Long Title of the Act provides: "An Act to make new provision for the government of Northern Ireland for the purpose of implementing the agreement reached at multi-party talks on Northern Ireland set out in Command Paper 3883."

6 Robinson above n.3.

7 Declaration of Support para.2.

8 Para.5.

9 Constitutional Issues para.1(iii); British-Irish Agreement Article 1(ii).

10 Constitution of Ireland Article 3(1).

11 See McGarry and O'Leary above n.2. 
freedom from discrimination for all citizens, and of parity of esteem and of just and equal treatment for the identity, ethos, and aspirations of both communities." 12

The Agreement recognises the significance of human rights whatever constitutional arrangements are in place and the responsibility of the state (British or Irish) to ensure their promotion and protection.

The notion of rights (but not only rights) as safeguards figures prominently in the Agreement. This is evident in the section on Democratic Institutions in Northern Ireland, or Strand One. ${ }^{13}$ The idea underpinning this part of the Agreement is to create institutions in Northern Ireland which are inclusive and subject to safeguards to ensure the rights and interests of all sides of the community are upheld. Its consociational nature is evident in the Strand One arrangements which reflect a particular form of power-sharing government. ${ }^{14}$ The safeguards are there to secure a democratic purpose intrinsically linked to power-sharing and based on concerns about the adverse consequences of majoritarian forms of democracy in "divided societies". ${ }^{15}$ They exist to guarantee a form of representative democracy in which all sections of the community can participate. ${ }^{16}$ Rights form one part of this list of safeguards, which include: the European Convention on Human Rights; any Bill of Rights adopted for Northern Ireland; and the work of the Human Rights and Equality Commissions. ${ }^{17}$ Other safeguards relate to the proportionate allocation of Committee Chairs, Ministers and Committee Membership, special voting rules, human rights proofing, the Pledge of Office for Ministers as well as a Code of Conduct. ${ }^{18}$ Taken together these constitute an impressive array of protections, with the aim of securing full participation. The Northern Ireland Assembly has been suspended since October 2002. ${ }^{19}$

The human rights dimension is reflected in the Northern Ireland Act 1998 in a number of ways. A provision of an Act of the Assembly is not law if it is incompatible with the relevant provisions of the European Convention. ${ }^{20} \mathrm{~A}$ Minister, or Northern Ireland Department, has no power to make subordinate legislation or do any act which is incompatible with Convention rights. ${ }^{21}$ Mechanisms are in place within the Assembly to scrutinise whether proposed legislation is within its legislative competence. For example, the Presiding

12 Constitutional Issues para.1(v); British-Irish Agreement Article 1 (v).

13 E.g. para.5.

14 See O'Leary n.2 above. On consociationalism see Arend Lijphart Democracy in Plural Societies: A Comparative Exploration (1977); Arend Lijphart Patterns of Democracy: Government Forms and Performance in Thirty-Six Countries (1999); Michael Kerr Imposing Power-Sharing: Conflict and Coexistence in Northern Ireland and Lebanon (2005); Brendan O'Leary "Debating Consociational Politics: Normative and Explanatory Arguments" in S.J.R. Noel (ed.) From Power-Sharing to Democracy: Post-Conflict Institutions in Ethnically Divided Societies (2005) 3.

15 See Lijphart ibid.

16 Para.5.

17 ibid.

18 See paras.5-29.

19 Northern Ireland Act 2000 s.1; Northern Ireland Act (Suspension of Devolved Government) Order 2002 (SI 2002/2574).

20 Northern Ireland Act 1998 s.6(2)(c).

21 Northern Ireland Act 1998 s.24(1)(a). 
Officer ensures that the provisions of proposed legislation are scrutinised prior to their introduction to the Assembly. ${ }^{22}$ The Northern Ireland Human Rights Commission also has a role in offering advice on the compatibility of a Bill with human rights. ${ }^{23}$ "Human rights" in the relevant provisions of the Northern Ireland Act 1998 are not confined to the Convention rights. ${ }^{24}$ This allows the Commission to draw upon a range of human rights standards when providing advice to the Assembly. The relevant Minister is required to state that a new Bill is within the legislative competence of the Assembly. ${ }^{25}$ The Attorney General for Northern Ireland has the power to refer the issue of competence to the Judicial Committee of the Privy Council for decision. ${ }^{26}$ The Assembly Committees also have a significant role in the legislative process. ${ }^{27}$ There is, however, no human rights committee, even though the Agreement indicated the need for human rights proofing. Reference to human rights was to be found in the Executive Committee's Programme for Government 2002-2005.28 The Northern Ireland Assembly, when functioning, did address human rights matters. For example, The Northern Ireland Assembly debated the work of the Human Rights Commission on 25 September 2001. ${ }^{29}$ The debate in the Assembly broadly reflected the views of the political parties on both the Commission and the Bill of Rights process. There was little explicit reference to enforcement of a Bill of Rights, however, some hard questions about the Bill of Rights process were raised. A concern about a "maximalist human rights culture" was expressed, reflecting unease among some politicians about the impact of expansive human rights protections on the democratic process. ${ }^{30}$

Strand Two of the Agreement deals with North-South matters - the all Ireland dimension. The absence of any mention of rights protection in Strand Two (North/South Ministerial Council) is compensated for in later sections of the Agreement, where reference is made to the rights of everyone living on the island of Ireland in the context of the work of the two Human Rights Commissions.

22 Northern Ireland Act 1998 s. 10.

23 Northern Ireland Act 1998 s.69(4)

24 Northern Ireland Act 1998 s.69(11)(b).

25 Northern Ireland Act 1998 s.9.

26 Northern Ireland Act 1998 s.11. See the Constitutional Reform Act 2005 for the role of the new Supreme Court.

27 Northern Ireland Act 1998 s. 13

28 Programme for Government: Making a Difference 2002-2005 (2001), e.g. p.13: "One of our key challenges is to develop a society - a wider community - in which all citizens can fully and freely participate. In such a community, equality, human rights, mutual trust and respect must be core values and citizens must be able to realise their full potential and live free from poverty."

29 NI Assembly, Official Report, 25 September 2001. Dr. Esmond Bernie MLA moved the motion: "That this Assembly believes, in the context of the development of a Bill of Rights, that the Northern Ireland Human Rights Commission has failed to discharge its remit, as given to it by the Belfast Agreement, in its various contributions to the debate on developing human rights in Northern Ireland."

30 ibid. 
Strand Three deals with British-Irish relations and the "totality of relationships among the peoples of these islands". ${ }^{31}$ It includes the creation of a British-Irish Council and a British-Irish Intergovernmental Conference. There is limited reference to rights, but they are listed as matters to be addressed by the Intergovernmental Conference. ${ }^{32}$ Provision for these new institutions can be found in the 1998 Act, in Irish law and in bilateral agreements between the British and Irish governments. ${ }^{33}$

Human rights are fully addressed in the section of the Agreement entitled Rights, Safeguards and Equality of Opportunity. Here the parties affirm rights to the following: free political thought; freedom and expression of religion; to pursue democratically national and political aspirations; to seek constitutional change by peaceful and legitimate means; to choose one's place of residence; to equal opportunity in all social and economic activity, regardless of class, creed, disability, gender or ethnicity; to freedom from sectarian harassment; and the right of women to full and equal political participation. ${ }^{34}$ The rest of the section is concerned with the commitments of the British and Irish governments. The British government agreed to incorporate the European Convention on Human Rights. ${ }^{35}$ The government also agreed to a new statutory equality duty which would "create a statutory obligation on public authorities in Northern Ireland to carry out all their functions with due regard to the need to promote equality of opportunity in relation to religion and political opinion; gender; race; disability; age; marital status; dependants; and sexual orientation". ${ }^{36}$

The Agreement refers to the establishment of a new Northern Ireland Human Rights Commission which would be invited to consult and advise on a Bill of Rights for Northern Ireland. ${ }^{37}$ The Commission began its work on 1 March 1999 and the Bill of Rights process commenced one year later on 1 March 2000 .

The attempt to embed human rights principles in Northern Ireland is not confined to the democratic and other institutions mentioned above. Human rights principles have, for example, framed the debates on policing and criminal justice. What is distinct about current developments in Northern Ireland is that they go beyond the piecemeal enunciation of principles. The intention appears to be to "mainstream" human rights norms in the governance of Northern Ireland. The idea being, as in the equality debates,

31 Para.1.

32 British-Irish Intergovernmental Conference para.6.

33 Agreement establishing a British-Irish Intergovernmental Conference (2000) UKTS no.54, (1999) Cm 4295; Agreement establishing a British-Irish Council (2000) UKTS no.55, (1999) Cm 4296. Both these British-Irish agreements entered into force on 2 December 1999.

34 Rights, Safeguards and Equality of Opportunity para.1.

35 Rights, Safeguards and Equality of Opportunity para.2. See the Human Rights Act 1998.

36 Rights, Safeguards and Equality of Opportunity para.3. See s.75 Northern Ireland Act 1998.

37 Rights, Safeguards and Equality of Opportunity paras.4-5. 
that human rights also become a central and normal part of processes of policy formulation and implementation. ${ }^{38}$

The Irish government agreed to implement a number of human rights commitments through the Agreement, in particular to "take steps to further strengthen the protection of human rights in its jurisdiction". ${ }^{39}$ Taking account of the work of the All-Party Oireachtas Committee on the Constitution, and the Report of the Constitution Review Group ${ }^{40}$ the Irish government agreed to advance proposals to strengthen and underpin the constitutional protection of human rights. ${ }^{41}$ The Agreement states that these proposals should draw upon the European Convention on Human Rights "and other international legal instruments in the field of human rights" and that the issue of incorporation of the Convention be further examined. ${ }^{42}$ The overriding purpose is to ensure "at least an equivalent level of protection of human rights as will pertain in Northern Ireland". ${ }^{43}$ This commitment to equivalence can be traced directly to the constitutional basis of the Agreement. ${ }^{44}$ As noted, the basic idea is that whichever state exercises jurisdiction over Northern Ireland there should be no difference in the levels of human rights protection. The concept of equivalence has given rise to considerable debate on its precise implications in the Irish context. There are two points to note. First, the constitutional context of the UK and Ireland differs. Ireland has a "written constitution" with rights contained in it. Second, equivalence relates to the possibility of a choice about constitutional status, in other words, that the Unionist community in Northern Ireland would suffer no loss in terms of human rights guarantees in the event of Irish unity.

The Irish government also agreed that it would: establish a Human Rights Commission; ratify the Council of Europe Framework Convention on National Minorities as quickly as possible; implement enhanced employment equality legislation; introduce equal status legislation; and "continue to take further active steps to demonstrate its respect for the different traditions on the island of Ireland". ${ }^{45}$ The Irish government has acted on a number of these, with the enactment of the Equal Status Act 2000 and the Employment

38 See Christopher McCrudden "Mainstreaming Human Rights" in Colin Harvey (ed.) Human Rights in the Community: Rights as Agents for Change (2005) chap.2.

39 Rights, Safeguards and Equality of Opportunity para.9. See also the British-Irish Agreement Article 2: "The two Governments affirm their solemn commitment to support, and where appropriate implement, the provisions of the Multi-Party Agreement."

40 See the All-Party Oireachtas Committee on the Constitution Report of the Constitution Review Group (1996). The Committee has published ten progress reports thus far.

41 Rights, Safeguards and Equality of Opportunity para.9.

42 Rights, Safeguards and Equality of Opportunity para.9.

43 Rights, Safeguards and Equality of Opportunity para.9.

44 See Colm O'Cinneide Equivalence in Promoting Equality: The Implications of the Multi-Party Agreement for the Further Development of Equality Measures for Northern Ireland and Ireland (December 2005).

45 Rights, Safeguards and Equality of Opportunity para.9. 
Equality Act 1998. ${ }^{46}$ The Irish Human Rights Commission was established by the Human Rights Commission Act 2000 and the Human Rights Commission (Amendment) Act 2001. The Irish government has also "incorporated" the European Convention on Human Rights into domestic law. ${ }^{47}$

The Agreement does not envisage the two Human Rights Commission working in isolation from each other. It proposed a Joint Committee of both Commissions which would operate as a "forum for consideration of human rights issues in the island of Ireland". ${ }^{48}$ One of the matters for consideration is a charter which would reflect and endorse agreed measures for the protection "of the fundamental rights of everyone living in the island of Ireland". ${ }^{49}$ The Joint Committee was established in November 2001, and work has been carried out on, among other things, the Charter of Rights with the publication of a pre-consultation document setting out possible options. ${ }^{50}$

This is an outline only of the more important aspects of the Agreement and the 1998 Act as they relate to human rights promotion and protection. As noted, the institutions of the Agreement and Northern Ireland Act 1998 were suspended by the Secretary of State for Northern Ireland on 14 October 2002 under the terms of the Northern Ireland Act 2000. ${ }^{51}$ The Secretary of State and his team of "direct rule" Ministers run the relevant Northern Ireland Departments while the Northern Ireland Assembly is suspended. The commitment to human rights has been repeated in the official documentation from both governments thus far. For example, the Joint Declaration from April 2003 makes reference to human rights ${ }^{52}$ and the Comprehensive Agreement proposed by both governments in December 2004 lists equality and human rights as at the "heart of the new dispensation in Northern Ireland". .53

\section{The Northern Ireland Human Rights Commission}

There has, in recent times, been a steady increase in the number of national institutions for the protection of human rights. ${ }^{54}$ For example, a new national

46 Ireland ratified the Framework Convention on National Minorities in 1999 and it has submitted two reports to the Framework Convention's Advisory Committee.

47 European Convention on Human Rights Act 2003.

48 Rights, Safeguards and Equality of Opportunity para. 10.

49 Rights, Safeguards and Equality of Opportunity para.10. See Brice Dickson "A Charter of Rights for the Island of Ireland", University College, Cork, 2 October 2004.

50 Joint Committee Pre-Consultation Paper on Charter of Rights for the Island of Ireland (September 2004). The Joint Committee has also published: A User's Guide to the International Convention on the Elimination of Racial Discrimination (September 2003).

51 See above n. 19.

52 Joint Declaration by the British and Irish Governments paras.25-33.

53 Proposals by the British and Irish Governments for a Comprehensive Agreement (December 2004).

54 See International Council on Human Rights Policy Assessing the Effectiveness of National Human Rights Institutions (2005). 
human rights commission has been established in Afghanistan. ${ }^{55}$ There will soon be a Commission for Equality and Human Rights in Britain ${ }^{56}$ and there may be a Scottish Commissioner for Human Rights. ${ }^{57}$

The nature and functions of these bodies differ, but one objective is to provide an institutional home, and more secure basis, in national contexts for human rights protection and promotion..$^{58}$ The opportunities and risks are well known. National human rights commissions may be used by governments primarily for external purposes. It is useful within the international community for a state to point to the existence of an institution like this as an example of how it is taking human rights seriously. ${ }^{59}$ Human Rights Commissions may not be sufficiently independent from government in practice and thus refrain from tackling difficult issues. The process of appointment of Commissioners to national institutions can cause concerns. However, Commissions have potential, particularly if they are able to act independently and rigorously seek to measure and improve "human rights performance" in the state.

The Northern Ireland Human Rights Commission is not the first such body. The Northern Ireland Constitution Act 1973 provided for the establishment of the Standing Advisory Commission on Human Rights (SACHR). ${ }^{60}$ SACHR carried out some important and influential work ${ }^{61}$ but suffered from a number of well-documented weaknesses, including a limited mandate. ${ }^{62}$ The intention, as expressed in the Agreement, was to replace it with a body which would have, "an extended and enhanced role beyond that ... exercised by [SACHR]". ${ }^{63}$ The new Commission was intended to reflect the community balance in Northern Ireland and be independent of government. ${ }^{64}$

55 See http://www.aihrc.org.af. The Constitution of Iraq 2005 provides for the establishment of a Supreme Human Rights Commission. For further details see: http://www.nhri.net.

56 Equality Act 2006.

57 At the time of writing the Scottish Commissioner for Human Rights Bill is before the Scottish Parliament. However, in February 2006 the Justice 1 Committee of the Parliament refused to endorse the Bill. See the article by Aidan O'Neill for further details on developments in Scotland.

58 See generally Bertrand Ramcharan (ed.) The Protection Role of National Human Rights Institutions (2005); Brice Dickson "The Contribution of Human Rights Commissions to the Protection of Human Rights" [2003] Public Law 272; Speech of Dr Maurice Manning, President of the Irish Human Rights Commission, Queen's University Belfast, $10^{\text {th }}$ June 2005.

59 See the references to the Indian Human Rights Commission in Chahal v UK (1996) 23 EHRR 413.

60 Northern Ireland Constitution Act 1973 s.20

61 See, e.g. Standing Advisory Commission on Human Rights Report on Fair Employment, Religious and Political Discrimination and Equality of Opportunity in Northern Ireland (1987).

62 SACHR was dissolved, see Northern Ireland Act 1998 s.72.

63 Rights, Safeguards and Equality of Opportunity para.5.

64 See generally Stephen Livingstone "The Northern Ireland Human Rights Commission" (1999) 22 Fordham International Law Journal 1465; Stephen Livingstone and Rachel Murray Evaluating the Effectiveness of National Human Rights Institutions: The Northern Ireland Human Rights Commission with Comparisons from South Africa (January 2005). 
The functions and powers of the Commission are set out in the 1998 Act and largely reflect the references contained in the Agreement.

"A new Northern Ireland Human Rights Commission, with membership from Northern Ireland reflecting the community balance, will be established by Westminster legislation, independent of the Government, with an extended and enhanced role beyond that currently exercised by the Standing Advisory Commission on Human Rights, to include keeping under review the adequacy and effectiveness of laws and practices, making recommendations to Government as necessary; providing information and promoting awareness of human rights; considering draft legislation referred to them by the new Assembly; and, in appropriate cases, bringing court proceedings or providing assistance to individuals." 65

Part VII of the Northern Ireland Act 1998 provides for the establishment of the Commission. As noted, the Commission began its work in March 1999 and consists of a full-time Chief Commissioner and nine part-time Commissioners. ${ }^{66}$ In appointing Commissioners the Secretary of State is under a duty to ensure as far as practicable that they are representative of the community in Northern Ireland. ${ }^{67}$ The Commission's statutory functions include: keeping under review the adequacy and effectiveness in Northern Ireland of law and practice relating to the protection of human rights; the provision of advice to the Secretary of State and the Executive Committee of the Assembly on measures to be taken to protect human rights; and advice to the Assembly on whether a Bill is compatible with human rights. ${ }^{68}$ The Commission may provide assistance to individuals who wish to bring proceedings. ${ }^{69}$ In addition, the Commission has an education function in promoting understanding and awareness of the importance of human rights issues in Northern Ireland. ${ }^{70}$ In fulfilling this function it may undertake research and other activities. ${ }^{71}$ It has the power of investigation but it is currently a limited one. ${ }^{72}$ The Commission also has a casework function and it has provided assistance to a number of individuals. As noted, "human rights" in the relevant sections of the 1998 Act are not confined to Convention rights, thus permitting the Commission to draw upon the full range of international standards. ${ }^{73}$ The Commission has undertaken a review of its effectiveness and it made a number of recommendations to government

65 Rights, Safeguards and Equality of Opportunity para.5.

66 The current Chief Commissioner is Professor Monica McWilliams (2005-). The previous Chief Commissioner was Professor Brice Dickson (1999-2005).

67 Northern Ireland Act 1998 s.68(3).

68 Northern Ireland Act 1998 s.69.

69 Northern Ireland Act 1998 s.70. See also Re Northern Ireland Human Rights Commission [2002] UKHL 25. For comment see Anne Smith "Access to Intervene: The Northern Ireland Human Rights Commission and the Northern Ireland Act 1998" [2003] European Human Rights Law Review 423.

70 Northern Ireland Act 1998 s.69(6)(b).

71 Northern Ireland Act 1998 s.69(6). Significant Commission publications include: Human Rights and Victims of Violence (June 2003); The Hurt Inside: The imprisonment of women and girls in Northern Ireland (revised ed., June 2005).

72 Northern Ireland Act s.69(8).

73 Northern Ireland Act s.69(11)(b). 
in $2001 .^{74}$ The government responded to these recommendations in May $2002^{75}$ and in December 2004 indicated that it was minded to give the Commission the powers it had sought in relation to access to places of detention and the power to compel evidence and witnesses. ${ }^{76}$ In 2005 , the government published a consultation document on the powers of the Commission, broadly reflecting the position outlined in December 2004. ${ }^{77}$ The work of the Commission has also been examined by the Joint Committee on Human Rights ${ }^{78}$ and its report contains a number of useful recommendations. ${ }^{79}$

The Commission has responsibility for what is termed the "Bill of Rights process". ${ }^{80}$ The idea that Northern Ireland requires a Bill of Rights has been around for some time. ${ }^{81}$ There appears to have been a broad political consensus that it was a worthwhile venture, although there are differences of view on the detail. ${ }^{82}$ However, it is only with the adoption of the Agreement that the political aspiration has become a real possibility. ${ }^{83}$ The primary focus of the participants, however, was on securing overall political agreement on the structures needed to bring an end to the conflict. This political agreement provides the legitimacy for the Bill of Rights exercise. The Agreement states:

"The new Northern Ireland Human Rights Commission. . . will be invited to consult and to advise on the scope for defining, in Westminster legislation, rights supplementary to those in the European Convention on Human Rights, to reflect the particular circumstances of Northern Ireland, drawing as appropriate on international instruments and experience. These

74 Northern Ireland Human Rights Commission Report to the Secretary of State Required by Section 69(2) of the Northern Ireland Act 1998 (February 2001). See also Northern Ireland Human Rights Commission Briefing paper concerning the UK Government's Consultation Paper on the Review of the Powers of the Northern Ireland Human Rights Commission (July 2002); Northern Ireland Human Rights Commission The Commission's Powers - A Supplementary Report (April 2004).

75 Northern Ireland Office The Northern Ireland Human Rights Commission's Review of Powers Recommendations: A Paper for Consultation (May 2002).

76 NIO Press Release "Competition for Chief Commissioner of the Northern Ireland Human Rights Commission" 17 $7^{\text {th }}$ December 2004.

77 Northern Ireland Office The Powers of the Northern Ireland Human Rights Commission (November 2005).

78 Joint Committee on Human Rights Work of the Northern Ireland Human Rights Commission (2002-2003) 14 ${ }^{\text {th }}$ Report, HL Paper 131, HC 142 (15 $5^{\text {th }}$ July 2003).

79 ibid.

80 For extensive analysis of the process and its context see "Special Double Issue on the Proposed Bill of Rights for Northern Ireland" [2001] 52 Northern Ireland Legal Quarterly 229-406.

81 See Austen Morgan "What Bill of Rights?" [2001] 52 Northern Ireland Legal Quarterly 234.

82 See CAJ A Bill of Rights for Northern Ireland: Through the Years - the views of the political parties (July 2003).

83 Rights, Safeguards and Equality of Opportunity para.4. However, it is worth noting that the process can also be linked to the power of the Commission to advise the Secretary of State on "legislative and other measures which ought to be taken to protect human rights. .." Northern Ireland Act 1998 s.69(3). 
additional rights to reflect the principles of mutual respect for the identity and ethos of both communities and parity of esteem, and - taken together with the ECHR - to constitute a Bill of Rights for Northern Ireland. Among the issues for consideration by the Commission will be: the formulation of a general obligation on government and public bodies fully to respect, on the basis of equality of treatment, the identity and ethos of both communities in Northern Ireland; and a clear formulation of the rights not to be discriminated against and to equality of opportunity in both the public and private sectors."

The 1998 Act places a duty on the Secretary of State to request the advice referred to in the above paragraph. ${ }^{85}$ The Secretary of State requested this advice in March 1999.86 The consultation process was launched by the Commission on 1 March 2000 with events in Derry and Belfast. The Commission has stressed the inclusive nature of the process and its desire for innovation and creativity. There have been working groups, consultation documents, conferences, seminars and many other events. ${ }^{87}$ The timescale has been subject to amendment and the Commission has not as yet submitted its final advice. It has worked on a draft Bill of Rights which it published in September 2001 with an updated and revised version published in April 2004. ${ }^{88}$ In its proposed Strategic Plan for 2006-2009 one of the aims of the Commission is to build support for a Bill of Rights and work in partnership with others for its implementation. ${ }^{89}$ The Commission has expressed its continuing support for the idea of a roundtable forum to take forward the Bill of Rights process. This forum would be composed of the political parties and representatives of civic society, with an international chair and an independent secretariat. The forum was expressly referred to in the Joint Declaration of April 2003 and the Comprehensive Agreement of December

4 ibid.

85 Northern Ireland Act 1998 s.69(7).

86 Brice Dickson “Introduction” [2001] 52 Northern Ireland Legal Quarterly 229, at 230.

87 For details see http://www.nihrc.org.

88 Northern Ireland Human Rights Commission Making a Bill of Rights for Northern Ireland (September 2001); Northern Ireland Human Rights Commission Progressing a Bill of Rights for Northern Ireland (April 2004); Northern Ireland Human Rights Commission Summary of Submissions on a Bill of Rights (July 2003). For comment on the Commission's proposals see Christopher McCrudden "Not the Way Forward: Some Comments on the Northern Ireland Human Rights Commission's Consultation Document on a Bill of Rights for Northern Ireland" (2001) 52 Northern Ireland Legal Quarterly 372. See also the work of the Human Rights Consortium (established in 2000 to ensure participation in the Bill of Rights process and to call for a strong and inclusive Bill of Rights) Frequently Asked Questions about a Bill of Rights for Northern Ireland (June 2005); A Bill of Rights - what it means to us (August 2004); A Bill of Rights - What it means to me (March 2005).

89 Northern Ireland Human Rights Commission Strategic Plan 2006-2009: Consultation Document (November 2005). 
2004 included further reference to it. ${ }^{90}$ Both governments remain committed to the establishment of the roundtable.

\section{Human Rights as part of the mainstream?}

A major focus of debate since 1998 has been on "mainstreaming human rights". ${ }^{91}$ This reflects the view that human rights should not be viewed as an add on, but as an intrinsic part of the policy formulation, development and implementation process; that human rights become a mainstream feature of political and legal life in Northern Ireland. The Human Rights Act 1998 was intended to embed a culture of respect for human rights, an aspiration that goes further than reliance on litigation alone.

There is a wide range of public bodies in Northern Ireland with an express interest in rights, for example: Equality Commission for Northern Ireland; Community Relations Council; Parades Commission; Sentence Review Commission; Northern Ireland Commissioner for Children and Young People; Criminal Justice Inspection (Northern Ireland); Judicial Appointments Commission; Interim Victims' Commissioner; and others. These bodies are expected to take, among other things, human rights seriously in their work. As noted, in the areas of policing and criminal justice there has been a sustained attempt to stress the centrality of human rights. ${ }^{92}$ The work of the Policing Board and the Criminal Justice Inspectorate is of particular importance in this regard. ${ }^{93}$

90 See Annex A "Secretary of State further consults with parties and announces arrangements for an independently facilitated forum on a Bill of Rights for Northern Ireland including details of an independent facilitator". See also Joint Communiqué, British-Irish Intergovernmental Conference, London, 1 February 2006: "The Conference also discussed human rights issues and specifically the question of a roundtable forum on a Bill of Rights for Northern Ireland. The British Government will work with the political parties and civic society to determine how best to build cross-community consensus on the issue."

91 Christopher McCrudden "Mainstreaming Human Rights" in Harvey (ed.) Human Rights in the Community: Rights as Agents for Change (2005) chap.2.

92 Arising, for example, in the policing context from the recommendations of the "Patten Report" (A New Beginning: Policing in Northern Ireland - The Report of the Independent Commission on Policing in Northern Ireland - September 1999) and in the criminal justice context from the Criminal Justice Review (Review of the Criminal Justice System in Northern Ireland - March 2000). Both reports stressed the centrality of a rights-based approach. For analysis of the policing debate see Mary O'Rawe "Transitional Policing Arrangements in Northern Ireland: The Can't and the Won't of the Change Dialectic" (2003) 26 Fordham International Law Journal 1015; John McGarry and Brendan O'Leary Policing Northern Ireland: Proposals for a new start (1999); Mary O'Rawe and Linda Moore Human Rights on Duty: Principles for better policing - International lessons for Northern Ireland (1997).

93 The Policing Board monitors the compliance of the Police Service of Northern Ireland with the Human Rights Act 1998, see Police (Northern Ireland) Act 2000 s.3(3)(b)(ii). See Northern Ireland Policing Board Human Rights Annual Report 2005. Keir Starmer QC was appointed as Human Rights Advisor to the Policing Board in February 2003 and Jane Gordon was appointed as assistant to the Board's Human Rights Advisor in July 2003. See also Northern Ireland Policing Board Report on the Policing of the Ardoyne Parades 12 th July 2005 and the Whiterock Parade 10 ${ }^{\text {th }}$ September 2005 (December 2005). For an example of a 


\section{The Human Rights Act in Northern Ireland}

The Human Rights Act 1998 entered into force throughout the UK on 2 October 2000 and applies in Northern Ireland. As in the rest of the UK, it is of particular significance in considering the framework of human rights protection and promotion. It has been extensively cited and used in the Northern Irish courts. ${ }^{94}$ There is now a large body of case law on the Act and the application of Convention rights. These cases range from those like McCaughey and Grew ${ }^{95}$ dealing with Article 2 of the Convention, Department for Social Development $v$ Shaun MacGeagh, ${ }^{96}$ involving the Child Support Order and its regulations and the question of compatibility with Articles $6^{97}$ and 14 as well as Protocol 1 Article 1, to cases like In re Shay Donnelly, ${ }^{98}$ dealing with court proceedings for the possession of a house and compliance with Article 8. ${ }^{99}$ Convention rights have been raised in cases such as $A R v$ Homefirst Community Trust ${ }^{100}$ where the making of a care order was held to violate Article 8. This can be contrasted with Re Misbehavin' Ltd ${ }^{101}$ where the Northern Ireland Court of Appeal held that Belfast City Council had failed in refusing to grant a licence to conduct a proper balancing exercise in relation to Article 10 and Protocol 1 Article 1 of the Convention.

human rights-based challenge to the new arrangements for police recruitment see Re Parsons [2003] NICA 20. The Criminal Justice Inspectorate was established by the Justice (Northern Ireland) Act 2002 and following the recommendations of the Criminal Justice Review. The Inspectorate has developed a "common core" matrix within which equality and rights play a central part. Respect for human rights and equality is listed under "even-handedness" which is one of the five elements of the "common core" of the inspection process, Criminal Justice Inspectorate Prospectus for a new Criminal Justice Inspectorate in Northern Ireland (January $2004)$ at 15. See also Northern Ireland (Miscellaneous Provisions) Bill 2006 and Northern Ireland Office Devolving Policing and Justice in Northern Ireland - A Discussion Paper (2006).

94 See Brice Dickson "Northern Ireland" in Lord Lester of Herne Hill QC and David Pannick QC Human Rights Law and Practice (2nd ed., 2004) pp.527-587.

95 [2005] NICA 1. See also Re Jordan [2004] NICA 29. Both cases are on appeal to the House of Lords at the time of writing. Other cases of note on Article 2 include: Re Committee on the Administration of Justice and another [2005] NIQB 25; Re Anderson [2005] NIQB 61; Re McBride [2003] NICA 23; Re Meehan [2003] NICA 34.

96 [2005] NICA 28.

97 There are a considerable number of Article 6 cases, see e.g.: $R$ v McQuade [2005] NICA 2; Walsh v Director of the Assets Recovery Agency [2005] NICA 6; $R$ v McKeown [2004] NICA 41.

9812 December 2003.

99 Other Article 8 cases of note include: AR v Homefirst Community Trust [2005] NICA 8; McConway v Northern Ireland Prison Service [2004] NICA 44; Family Planning Association of Northern Ireland $\mathrm{v}$ Minister of State for Health, Social Services and Public Safety [2004] NICA 39; Re Stewart's Application [2003] NI 149.

100 [2005] NICA 8.

101 [2005] NICA 35. 


\section{Northern Ireland and international human rights law}

Northern Ireland is part of the UK. The UK is state party to a range of international human rights conventions and is responsible for ensuring compliance in Northern Ireland with relevant international standards. There is an international dimension to human rights protection in Northern Ireland and international mechanisms are often used. The European Convention on Human Rights, for example, was familiar to lawyers, NGOs and others in Northern Ireland long before the enactment of the Human Rights Act 1998. ${ }^{102}$ Many cases have gone to the European Commission/Court of Human Rights challenging law and practice. ${ }^{103}$ The Northern Ireland Human Rights Commission and human rights NGOs, such as the Committee on the Administration of Justice, have made practical use of the international mechanisms to argue for human rights reform. A useful example - many others could be cited - is the work of the Human Rights Commission and NGOs on the UK's report to the UN Committee against Torture. ${ }^{104}$

\section{Equality in Northern Ireland}

\section{Mainstreaming Equality}

Human rights and equality are foundational principles of the Belfast Agreement. The Declaration of Support provides:

"We are committed to partnership, equality and mutual respect as the basis of relationships within Northern Ireland, between North and South, and between these islands." 105

Equality is referred to in the statement of Constitutional Issues, ${ }^{106}$ and there is, as noted, a section of the Agreement addressing Rights, Safeguards and Equality of Opportunity. The institutional structures of internal powersharing, as well as the North-South and East-West dimensions, reflect a commitment to national equality, in addition to the references to social equality. ${ }^{107}$ Several of the rights listed relate directly to equality. For example, "the right of women to full and equal political participation" and

102 See Dickson n.94 above pp.529-540.

103 E.g. Shannon v UK, judgment of 4 October 2005; Brannigan and McBride v UK (1993) 17 EHRR 539; Brogan v UK (1988) 11 EHRR 117; Dudgeon v UK (1981) 4 EHRR 149; Ireland v UK (1978) 2 EHRR 25; McCann v UK (1995) 21 EHRR 97; McShane v UK (2002) 35 EHRR 23; Finucane v UK (2003) 37 EHRR 656; Kelly v UK (2002) 34 EHRR 553; Jordan v UK, judgment of 4 May 2001; McKerr v UK, judgment of 4 May 2001; Shanaghan $\mathrm{v} U K$, judgment of 4 May 2001.

104 See UN Committee against Torture Conclusions and recommendations: UK UN Doc. UNCAT/C/CR/33/3, 10 December 2004. The Committee recommended: "the State Party should consider designating the Northern Ireland Human Rights Commission as one of the monitoring bodies under the Optional Protocol. .."

105 Para.3.

106 Para.1(v).

107 See generally Christopher McCrudden "Mainstreaming Equality in the Governance of Northern Ireland" (1999) 22 Fordham International Law Journal 1696. 
"the right to equal opportunity in all social and economic activity, regardless of class, creed, disability, gender or ethnicity". ${ }^{108}$

As noted, the two governments agreed to support and implement measures on both human rights and equality. The British government committed itself to the following:

"Subject to the outcome of the public consultation underway, the British Government intends, as a particular priority, to create a statutory obligation on public authorities in Northern Ireland to carry out their functions with due regard to the need to promote equality of opportunity in relation to religion and political opinion; gender; race; disability; age; marital status; dependants; and sexual orientation. Public bodies would be required to draw up statutory schemes showing how they would implement this obligation. Such schemes would cover arrangements for policy appraisal, including an assessment of impact on relevant categories, public consultation, public access to information and services, monitoring and timetables."109

The conclusion of the Agreement coincided with extensive discussions on the institutional protection of equality in Northern Ireland and in the Agreement the British government set out its preference for a single Equality Commission to replace the existing bodies: "Such a unified Commission will advise on, validate and monitor the statutory obligation and will investigate complaints of default." 110 The Agreement also states:

"It will be open to a new Northern Ireland Assembly to consider bringing together its responsibilities for these matters into a dedicated Department of Equality." 111

The British government committed to making "rapid" progress with, for example:

"measures on employment equality included in the recent White Paper ('Partnership for Equality') and covering the extension and strengthening of anti-discrimination legislation, a review of the national security aspects of the present fair employment legislation at the earliest possible time, a new more focused Targeting Social Need initiative and a range of measures aimed at combating unemployment and progressively eliminating the differential in unemployment rates between the two communities by targeting objective need." 112

There are other references to equality in the Agreement, but this captures the main elements.

108 Rights, Safeguards and Equality of Opportunity para.1.

109 Rights, Safeguards and Equality of Opportunity para.3.

110 Rights, Safeguards and Equality of Opportunity para.6.

111 Rights, Safeguards and Equality of Opportunity para.7.

112 Rights, Safeguards and Equality of Opportunity para.2(iii). 
The Equality Commission for Northern Ireland was established by the Northern Ireland Act 1998 and it started work on 1 October 2000. ${ }^{113}$ The functions of the existing bodies were transferred to the single Equality Commission for Northern Ireland. ${ }^{114}$ The Commission inherited the existing legal framework and no Single Equality Act has yet been enacted. ${ }^{115}$ As is well known there are distinctive features in equality law in Northern Ireland, for example, the mechanisms in place to address inequality between the two main communities. ${ }^{116}$

The introduction of an innovative statutory duty to promote equality of opportunity in relation to listed grounds has generated much comment. ${ }^{117}$ This attempt to "mainstream" equality in Northern Ireland has provoked considerable debate about positive duties. Section 75 entered into force in January 2000 so there is now extensive practical experience on which to base assessments. ${ }^{118}$ The Northern Ireland Act 1998 provides:

113 Northern Ireland Act 1998 Part VII.

114 Northern Ireland Act 1998 s.74. The bodies were: Fair Employment Commission for Northern Ireland; Equal Opportunities Commission for Northern Ireland; Commission for Racial Equality for Northern Ireland; and the Northern Ireland Disability Council.

115 Special Educational Needs and Disability (Northern Ireland) Order 2005; Disability Discrimination Act (Amendment) Regulations (Northern Ireland) 2004; Employment Equality (Sexual Orientation) Regulations (Northern Ireland) 2003; Equality (Disability etc)(Northern Ireland) Order 2000; Fair Employment and Treatment (Northern Ireland) Order 1998 (as amended); Race Relations (Northern Ireland) Order 1997 (as amended); Sex Discrimination (Northern Ireland) Order 1976 (as amended). See also Office of the First Minister and Deputy First Minister A Single Equality Bill for Northern Ireland: A Discussion Paper on options for a Bill to harmonise, update and extend, where appropriate, anti-discrimination and equality legislation in Northern Ireland (June 2004); Office of the First Minister and Deputy First Minister Single Equality Bill: Responses to Consultation (March 2005); Equality Commission for Northern Ireland Response to OFMDFM Consultation Paper 'A Single Equality Bill for Northern Ireland' (November 2004).

116 Christopher McCrudden "Northern Ireland, the Belfast Agreement, and the British Constitution" in Jowell and Oliver (eds.) The Changing Constitution (5 ed. 2004) 195, at 229-230; Standing Advisory Commission on Human Rights Fair Employment Law in Northern Ireland: debates and Issues (1996).

117 Northern Ireland Act 1998 s.75 and sch.9. For a comprehensive analysis see Christopher McCrudden above n.107. There is also a duty to "have regard to the desirability of promoting good relations between persons of different religious belief, political opinion or racial group" see Northern Ireland Act 1998 s.75(2) and also Office of the First Minister and Deputy First Minister A Shared Future: Policy and Strategic Framework for Good Relations in Northern Ireland (March 2005).

118 The Joint Declaration of April 2003 provided for the establishment of a review of the operation of 5.75 by the British government, with the Equality Commission and other interested parties. See Eithne McLaughlin and Neil Faris The Section 75 Equality Duty - An Operational Review: A Report Prepared for the Northern Ireland Office as the First Stage of the Review (November 2004). See also Annex B to the report: Christopher McCrudden Mainstreaming Equality in Northern Ireland 1998-2004: A Review of Issues Concerning the Operation of the Equality Duty in Section 75 of the Northern Ireland Act 1998. In addition to this, there is a statutory five year review of equality schemes to be undertaken by those 
"75(1) A public authority shall in carrying out its functions relating to Northern Ireland have due regard to the need to promote equality of opportunity -

(a) between persons of different religious belief, political opinion, racial group, age, marital status or sexual orientation;

(b) between men and women generally;

(c) between persons with a disability and persons without; and

(d) between persons with dependants and persons without."

A list system is adopted in relation to the definition of "public authority". ${ }^{119}$ A complex enforcement mechanism has been put in place. ${ }^{120}$ The Equality Commission must: keep the operation of section 75 under review; and offer advice to public authorities. ${ }^{121}$ The Equality Commission has a central role in enforcement of the duties through its monitoring of the equality schemes submitted by public authorities, but the Secretary of State for Northern Ireland may also become involved. Before submitting its equality scheme a public authority must consult "in accordance with directions given by the Commission ... representatives of persons likely to be affected by the scheme ... and such other persons as may be specified in the directions". ${ }^{122}$ The Equality Commission can approve the scheme or refer it to the Secretary of State. ${ }^{123}$ The Secretary of State can approve the scheme, request that the public authority submit a revised scheme or make an equality scheme for the public authority. ${ }^{124}$ The Equality Commission has the power to investigate a complaint received about the compliance of a public authority with an equality scheme. ${ }^{125}$ Such investigations can lead to directions being issued by the Secretary of State in relation to non-compliance. ${ }^{126}$ The Equality Commission, has so far, completed a considerable body of work in terms of both monitoring progress and providing guidance. ${ }^{127}$ In the next phase it

public bodies subject to s.75 (Northern Ireland Act 1998 schedule 9 para.8(3)) and the Equality Commission for Northern Ireland is conducting an effectiveness review. On the five year review see Equality Commission for Northern Ireland Guidance on Five Year Review of Equality Schemes by Public Authorities (November 2005).

119 Northern Ireland Act 1998 s.75(3).

120 Northern Ireland Act 1998 schedule 9; Equality Commission for Northern Ireland Section 75 of the Northern Ireland Act 1998: Guide to the Statutory Duties (revised February 2005); Equality Commission for Northern Ireland Section 75 of the Northern Ireland Act 1998 - Practical Guidance on Equality Impact Assessment (revised February 2005).

121 Northern Ireland Act 1998 schedule 9 para.1(a) and (b).

122 Northern Ireland Act 1998 schedule 9 para.5.

23 Northern Ireland Act 1998 schedule 9 para.6.

24 Northern Ireland Act 1998 schedule 9 para.7.

25 Northern Ireland Act 1998 schedule 9 paras.10-11.

126 Northern Ireland Act 1998 schedule 9 para.11(3)(b).

127 See above for details of guidance. Equality Commission for Northern Ireland Report on the Implementation of the Section 75 Statutory Duties 1 April 2002-31 March 2003 (2004); Full Report on the Implementation of the Section 75 Equality and Good Relations Duties by Public Authorities 1 January 2000-31 March 2002 (2003); Summary Report on the Implementation of the Section 75 Equality and Good Relations Duties by Public Authorities 1 January 2000 - 31 March 2002 (2003). 
appears that further thought will be given to how to make section 75 more effective in practice.

The mainstreaming approach does not negate established discrimination law guarantees. It seeks to build on existing protections in a proactive way that recognises the potential limits of established approaches. However, it is a mistake to assume that mainstreaming rules out more "coercive" methods, such as strategic litigation. A useful example is the case of Re Peter Neill. ${ }^{128}$ The case involved the use of Anti-Social Behaviour Orders in Northern Ireland and specifically the argument that the relevant law had not been introduced in compliance with section 75 of the Northern Ireland Act 1998. An investigation by the Equality Commission, which followed a complaint to the Commission from the Children's Law Centre, revealed that the Northern Ireland Office (NIO) had failed to conduct an equality impact assessment. The Commission concluded that the NIO should conduct an impact assessment. Before the High Court the NIO collaterally challenged the lawfulness of the Equality Commission report. Justice Girvan rejected the argument that the Anti-Social Behaviour (Northern Ireland) Order 2004 could be rendered invalid because of a failure to comply with section 75 , "section 75 does not contain any provision that a breach of that duty to have due regard to the need to promote equality of opportunity renders legislation invalid". ${ }^{129} \mathrm{He}$ went on to state:

"Alleged breaches of schemes are to be the subject of investigation and reporting with political consequences. It appears that the legislature, no doubt by way of a political compromise, opted for that route to remedy breaches of schemes rather than by conferring rights to be asserted by action or other litigious means." $" 130$

Justice Girvan went on to address the issue of the Commission report and its legal status. In addressing this question he noted:

"In approaching the provisions of section 75 and Schedule 9 one must bear in mind that these provisions are part of a statute intended to be a new constitution for Northern Ireland framed against the background of the history of Northern Ireland and the principles agreed in the so-called Good Friday Agreement. The Agreement was the product of multi-party negotiations and was intended to be a balanced and carefully nuanced constitutional arrangement. The equality provisions were a central part of the new arrangements. .."131

He also stated that the, "powers and duties of the Commission must be interpreted in a way that does not emasculate the role of the Commission". 132 Justice Girvan had the benefit of a written intervention on behalf of the

128 [2005] NIQB 66. See the following useful briefing note: Briefing Note by the Committee on the Administration of Justice on the Section 75 court challenge (September 2005). See also Re Northern Ireland Commissioner for Children and Young People [2004] NIQB 40.

129 Para.41.

130 Para.42.

131 Para.43.

132 Para.44. 
Committee on the Administration of Justice prepared by Robin Allen QC and Fiona Doherty which included a comprehensive examination of the scope and nature of section 75..$^{133}$ Justice Girvan argued that a "narrow legalistic analysis of the Commission report" was inappropriate and concluded that the Commission had acted lawfully. ${ }^{134}$ As noted, the Commission report was questioned in these proceedings by way of a collateral challenge. Justice Girvan attached significance to this fact:

"It seems unlikely that this dispute between the NIO and the Commission would have otherwise come before the court. Having regard to the whole structure of section 75 and Schedule 9 it is not the type of dispute that would generally be suitable for the litigious process." 135

Justice Girvan dismissed the application. The decision was appealed to the Northern Ireland Court of Appeal. ${ }^{136}$ Dismissing the appeal Lord Chief Justice Kerr stressed the need to focus on the context of this particular case. He noted that the failure of the NIO to comply with its Equality Scheme was the precise situation Schedule 9 was designed to address.

"It would be anomalous if a scrutinising process could be undertaken parallel to that for which the Commission has the express statutory remit. We have concluded that this was not the intention of Parliament ... The juxtaposition of sections 75 and 76 with contrasting enforcing mechanisms for the respective obligations ... strongly favour the conclusion that Parliament intended that, in the main at least, the consequences of a failure to comply with section 75 would be political, whereas the sanction of legal liability would be appropriate to breaches of the duty contained in section 76."137

On the issue of the availability of judicial review the Court of Appeal was not persuaded that:

"the existence of the Schedule 9 procedure ousts the jurisdiction of the court in all instances of breach of section 75 ... We incline to the opinion ... that there may well be occasions where a judicial review challenge to a public authority's failure to observe section 75 would lie. We do not consider it profitable at this stage to hypothesise situations where such a challenge might arise. This issue is best dealt with, in our view, on a case by case basis." 138

The debate over the effective implementation of section 75 is likely to continue given, in particular, impending reviews. Debates on equality are not confined to section 75. As noted, this simply builds on established equality measures applying in Northern Ireland but it has generated an

133 Para.44 and para.49.

134 Paras.49-50.

135 Para.50.

136 Re Peter Neill [2006] NICA 5.

137 ibid., para.28.

138 ibid., para.30. 


\section{Northern Ireland Legal Quarterly [Vol. 57, No. 1]}

extensive debate on the role of positive duties in ensuring that the objectives of equality and anti-discrimination law are met. ${ }^{139}$

\section{Conclusion}

This article outlines the basic framework in Northern Ireland relating to human rights and equality. There is a particular focus on the Belfast Agreement 1998 and developments since then. Whatever the precise legal status of the Agreement, its core concepts remain central to the "political constitution" of Northern Ireland. Human rights and equality are fundamental principles of the Agreement. However, disagreement continues over the precise meaning and implications of this. Northern Ireland is undergoing a conflict transformation process, underpinned by constitutional and international legal and political commitments. Human rights and equality are, in principle at least, central to this "new dispensation".

139 E.g. the Northern Ireland Act 1998 s.76 makes it "unlawful for a public authority carrying out functions relating to Northern Ireland to discriminate, or to aid or incite another person to discriminate, against a person or class of person on the ground of religious belief or political opinion." 